\title{
Asset Reconstruction in Banking Industry
}

\author{
Mallika S, Ramya T R, Shobana T
}

\begin{abstract}
The concept of Securitization can be identified as one of a major financial service. In general banks NPA gave a lot of trouble to banks in the way that banks could not sell the pledged asset to recover their money after defaults without court order. Indian banks have been plagued with the problem of NPA since 2006. The problem started when the banks started lending to heavy industries such as metal, mining sectors and to infrastructure development. Since the projects funded before were completed on time, the banks assumed that the future projects would also be completed at the same pace. The world economic slowdown of 2008 casted their effects on the Indian economy making the growth slow and reducing the demand. The projects started to miss deadlines and the banks showed least interest to restructure them. The promoters too inflated the cost of capital over a period of time which was left unchecked by the banks. However, this scenario changed with the introduction of SARFAESI Act 2002, where banks were authorized to recover money by selling pledged asset without any court intervention. The aforementioned Act also paved the concept for securitization. In this article, the primary focus is laid on understanding the workings of such ARC along with its performance in the Indian banking sector and the key challenges faced by such companies.
\end{abstract}

\section{Keywords : ARC, SARFAESI Act, NPA, Impaired Assets.}

\section{INTRODUCTION}

In the past year, Indian banking system was in abysmal limelight for PNB scam, exit of CEOs of ICICI bank, Axis bank and Yes bank and the RBI governor. Along with these issues, NPA problem popped up time and again. Insolvency and Bankruptcy Code was passed in 2016 which had overriding powers over the existing provisions, for the same purpose, in other acts. IBC aimed at fast tracking the recovery procedure for corporate, partnership firms and individuals and enabled bank to directly approach National Company Law Tribunal (NCLT) for recovering the bad loan amount. Mission Indradhanush was designed by the government for de-stressing the PSB's (Public Sector Banks), NPA .Out of 21 PSB, 11 were brought under the ambit of Prompt Corrective Measures (PCA) which barred, the banks with poor asset quality and low profits, from lending in the market. A whopping amount of Rs 65,000 crore is to be infused for the year 2018-19 to improve the

Revised Manuscript Received on December 05, 2019.

* Correspondence Author

Mallika S*, Assistant Professor, Department of Commerce, SRM Institute of Science and Technology, Tamil Nadu

Ramya T R, Assistant Professor, Department of Commerce (Honours), D G Vaishnav College, Chennai, India

Shobana T, Assistant Professor, Department of Commerce (SS), Ethiraj College For Women, Chennai, India capital adequacy of the PSBs. The merger of Dena bank which had high NPA at 22\%* with Vijaya bank and Bank of Baroda was proposed by the government leading to dissatisfaction among bank employees. Despite the above measures, the RBI has predicted that the NPAs may rise to $12.2 \% * *$ from $11.6 \% * *$ by March 2019.Adding to the woes, the ever-greening of stressed assets were done by the banks. The Debt Recovery Tribunal was yielding little results as the banks were not able to recover the expected amount from the defaulters. The SARFAESI Act was enacted in the year 2002, giving an option to the bank to recover the NPAs without going to DRT.

The act made way for formation of Securitization or Reconstruction Company which can take over the NPAs from bank. This article focuses on the working of such Asset Reconstruction Companies (ARC) in India.

\section{ASSET MANAGEMENT COMPANY}

With a steady increase in the total lending rate, the problem of NPAs increased in the current FY too. This increase in NPA has also lead to a growth of the ARCs in India. In order to tap its full potential, the government allowed $100 \%$ FDI in ARC through automatic investment route. Foreign Management Exchange Act (FEMA) was amended for the same.

ARC is a type of financial institution that buys the NPAs or bad assets from various banks to clean up their balance sheets. Or in other words, ARCs are in the business of buying bad loans from bank. The first ARC was ARCIL Premier ARC formed in the 2002. The ARCIL is sponsored by SBI, IDBI, ICICI and PNB. Edelweiss ARC is the largest ARC having an amount of Rs 39,000 as its Asset Under Management (AUM). As on October 2018, there are 29 ARCs approved by RBI.

\section{REVIEW OF LITERATURE}

Rajesh Kumar (2016) explores the legal provisions in SARFAESI Act for ARC and its functions specified by the act. The study also lists out the various ARCs in India. The author calls for more functional changes taking the risk factors faced by the ARCs in the market. Sanjeev Dhawan(2016) highlights the impact of NPA in Indian banking system and the various modes available for the banks to recover them. The study concludes saying that the government and the RBI is taking necessary steps to encourage more ARCs.

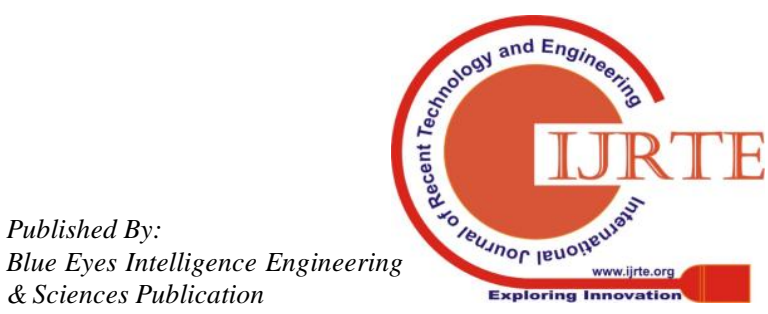


Jessy George (2017) studies the performance of 15 ARCs in India with the use of secondary data released by RBI. The author observed that time involved in the entire process of securitization should be reduced in order to yield maximum benefit from ARCs

\section{OBJECTIVES}

- To know the modus operandi of ARCs in India.

- To examine the performance of ARCs in India.

- To study the issues faced by ARC in India.

\section{MODUS OPERANDI OF ARC}

1. ARC will acquire the NPA, at a price which is lower than the book value, at discounted price say Rs1 crore NPA purchased at a lower price of Rs70 or 90 lakhs -usually discounted at a risk appropriate rate (herein referred to as haircut for the banks).

2. NPA is sold off to ARC along with the impaired asset which was pledged while taking loan from the bank. In order to raise funds for acquisition of these assets, the banks will issue security receipts which will be subscribed by the selling banks and $\mathrm{ARC}$ in a mandated ratio of 15:85. The Qualified Institutional Buyers (QIBs) such as mutual funds, SCBs and Foreign Institutional Investors (FIIs) can also acquire SRs.

3. ARC transfers the acquired assets to one or more trusts at the price at which the impaired assets were acquired from.

4. For each type of impaired asset that was acquired, a separate trust will be formed to issue and manage the security receipts. Now ARC will start legal procedure to sell the pledged security in the market. Any cash flow or profit or loss arising in between acquired price and realized price will be shared with the beneficiary of the trusts.

5. After selling the asset by clearing all litigations, the $\mathrm{ARC}$ will redeem (take back) the security receipts which are issued earlier for agreed price. Profit of ARC $=$ sale Price of security + interest on investment - purchase cost of NPA interest on security receipts - Expenses.

\section{PERFORMANCE OF ARC}

The banks in India can recover their NPAs through Lok Adalat, DRT and SARFAESI Act. IBC was a recent avenue available to the banks after it was passed in 2016 .

\begin{tabular}{|c|c|c|c|c|c|}
\hline S.NO & PARTICULARS & JUNE-2015 & JUNE-2016 & JUNE-2017 & JUNE-2018 \\
\hline 1. & Book value of acquired assets & 1,744 & 2,377 & 2,627 & 3,306 \\
\hline 2. & $\mathrm{SR}$ issued & 536 & 790 & 939 & 1,203 \\
\hline \multirow[t]{5}{*}{3.} & SR subscribed by: & & & & \\
\hline & a. Banks & 441 & 651 & 777 & 960 \\
\hline & b. ARCs & 73 & 114 & 142 & 202 \\
\hline & c. FIIs & 1 & 3 & 3 & 5 \\
\hline & d. Others(QIB) & 21 & 22 & 18 & 37 \\
\hline 4. & SR amount redeemed & 62 & 72 & 74 & 88 \\
\hline 5. & SR outstanding & 413 & 641 & 783 & 981 \\
\hline
\end{tabular}

The above table shows a stable increase in the NPAs taken up by ARCs from 2015-18, which reiterates the fact that banks are putting effort to stabilize their balance sheet. Apart from banks and ARCs for whom the subscription of SRs is mandatory, the FIIs participation has been positive over the years. The QIBs trend has its own share of both ups and downs over the span of 4 years. The SR outstanding has increased throughout all the years giving trouble to both the bank and the ARCs. Only a minuscule of the SR has been fully redeemed.

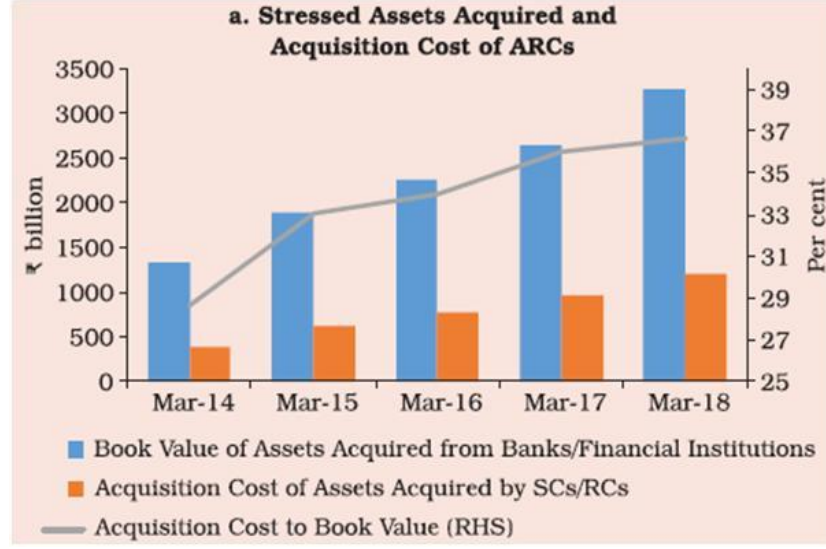

Chart (a) depicts growth of the assets acquired by ARCs in book value and cost at which NPAs were purchased by ARCs at a price lower than the book value in the books' of the bank. 
Both have shown a firm growth from the year 2014 to 2018, proving that ARCs is creating a strong place for itself in financial services market.

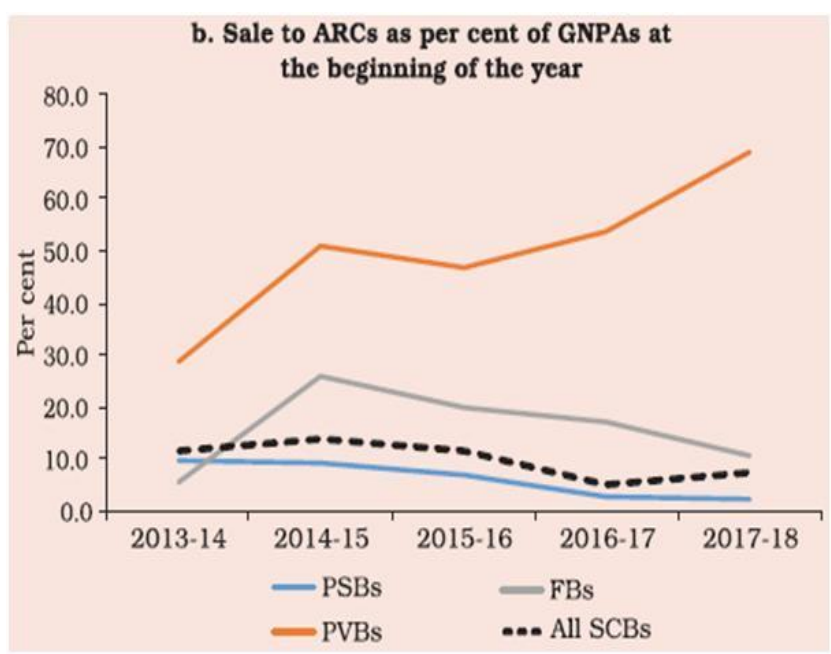

Chart (b) exhibits sale of NPAs by PSBs, PVBs, FBs and SCBs (Scheduled Commercial Banks) to the ARCs. The chart reveals the contrast attitude of the PSBs and the PVBs in selling their NPAs to the ARCs. From 2013 to 2018, the PVBs had a constant disposal of their NPAs to the ARCs whereas the PSBs were sluggish in doing so. The FBs had sold its NPAs more in 2014-15 and after that it has slowed down. Since the cleaning up of balance sheet of PSBs and FBs were taken into account for indicating the graph of SCBs (which includes all PSBs, RRBs etc), it has pulled down its numbers.

\section{PROBLEMS FACED BY ARC}

Funding: At some NPA bids, the banks expect a full cash basis purchase, which the ARC cannot afford. Canara Bank, Bank of India and Bank of Baroda openly stated that they would prefer cash to SRs. Such a circumstance makes process conducive, only for large ARCs like Edelweiss. Even though the RBI has raised the capital requirement of ARCs from Rs 2 crore to Rs 200 crore, it is not enough for small ARCs to buy NPAs from the banks. This paves way for the consolidation of small ARCs.

Pricing of NPAs: Since there is no legal ceiling on the haircut to be taken by the banks, purchase price of NPA by the ARC becomes the bone of contention while striking the deal. Moreover, banks prefer moving to the Lok Adalat, DRTs or NCLTs as they get a fair recovery deal rather than auctioning it to the ARCs. Highest recovery of NPA was through IBC amounting to Rs 4,925 billion (49.6\%)* in the FY 17-18, proves the above statement. SARFAESI Act recovery accounted for meagre Rs 265 billion (24.8\%)*.

Underdeveloped debt market: The uniqueness of the SRs is that they have features of both debt and equity, which brings the focus to the current debt market in India. It is facing liquidity crisis after the Infrastructure Leasing and Financial Services (IL\&FS) fiasco. So it is necessary that the debt market in the country is strengthened to withstand market condition.
Few takers for SRs: SARFAESI Act mandates that the SRs have to be sold only to QIBs through private placement. After bringing $100 \%$ FDI, foreign players like KKR have shown a keen interest in investing in SRs. But the participation is not enough reduce the current NPA of Rs 9,626 billion*.

\section{CONCLUSION}

The whole concept of Asset Reconstruction Companies is something which is relatively newly found. It is considered to be the responsibility of the companies to ensure that they maintain their NPA by involving good principles and practices like ensuring amicable methods to clean up their balance sheet. ARC's enables the bank to realize long term assets, manage problems of liquidity and improve recovery by exercising the power to take the possession of the securities, sell them and reduce Non Performing Assets. Now is the most appropriate time for ARCs to transform themselves into special situation funds, with deep operational capabilities to bring about a long-term revival in the business for business.

\section{REFERENCES}

1. Report on Trend and Progress of Banking in India by RBI

2. Report by Bankruptcy Board of India-2017-18.

3. Official website of ARCIL Premier ARChttp://www.arcil.co.in/aboutus/about-us.php

4. Official website of Edelweiss Serviceshttps://www.edelweissfin.com/web/edelweiss/asset-reconstruction

\section{AUTHORS PROFILE}

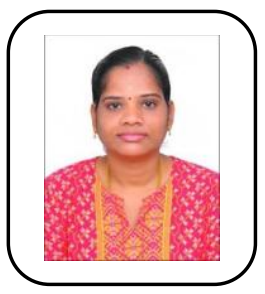

S. Mallika, Email: smallika5789@gmail.com M.Phil - D.B.Jain college (2012-2013), M.ComGuru nanak college (2010-2012), B.Com(CS) Justice Basheer Ahmed Sayeed College for Women (SIET)(2007-2010). HSC- Sarada vidhyalaya model hr. sec. school. (2005-2007). Worked as an Assistant Professor in the department of commerce (Honours). Working as an Assistant Professor in the department of comers, SRM institute of science and technology (Deemed to be university).

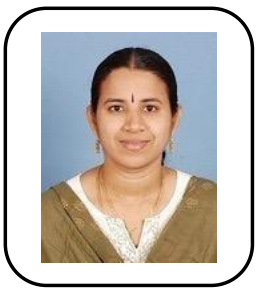

T.R.RAMYA, Working as a Assistant Professor (Part time) In B.Com (Hons) department in D.G.Vaishnav College. Worked as a Visiting Faculty in D.G.Vaishnav College \& Natesan Institute of management. In D.G.Vaishnav College, presently I am handling Marketing, Business Policy and Environment, Logistics and Supply chain management, Customer relation Management, Research Methodology and also handled Computer languages for management, Management Information System for MAHRM. In Natesan Institute of Management, I had handled Management Information System, Computer languages for management for MBA. Worked as a HR Executive in FlyJac Logistics, a logistics company with branches all over India handling cargo for large Corporate \& MNC's with an annual turnover of more than 100 Crores.

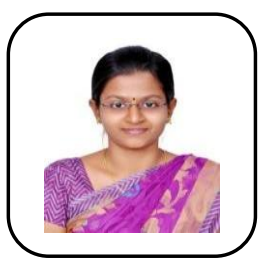

Ms. Shobana T. Working as an assistant professor in the department of commerce, Ethiraj College For Women (Autonomous). Worked as an audit assistant in Deloitte Audit \& Enterprise Risk Solutions India Private Ltd. Worked as an assistant professor in the department of commerce, Sathyabama University. Worked as an assistant professor in the department of commerce (Honors) Dwaraka Doss Goverdhan Doss Vaishnav College (Autonomous). 